\title{
Corrigendum: COVID-19 Effects on Livestock Production: A One Welfare Issue
}

\author{
Jeremy N. Marchant-Forde ${ }^{1 *}$ and Laura A. Boyle ${ }^{2}$ \\ ${ }^{1}$ United States Department of Agriculture - Agricultural Research Service, Livestock Behavior Research Unit, West Lafayette \\ IN, United States, ${ }^{2}$ Pig Development Department, Teagasc Animal and Grassland Research and Innovation Centre, Fermoy, \\ Ireland
}

Keywords: poultry, pigs, livestock production chain, one welfare, COVID-19

\section{OPEN ACCESS}

Approved by:

Frontiers Editorial Office Frontiers Media SA, Switzerland

*Correspondence: Jeremy N. Marchant-Forde jeremy.marchant-forde@usda.gov

Specialty section: This article was submitted to Animal Behavior and Welfare, a section of the journal

Frontiers in Veterinary Science

Received: 02 November 2020 Accepted: 03 November 2020 Published: 19 November 2020

Citation:

Marchant-Forde JN and Boyle LA (2020) Corrigendum: COVID-19 Effects on Livestock Production: A One Welfare Issue.

Front. Vet. Sci. 7:625372. doi: 10.3389/fvets.2020.625372

\section{A Corrigendum on}

COVID-19 Effects on Livestock Production: A One Welfare Issue

by Marchant-Forde, J. N., and Boyle, L. A. (2020). Front. Vet. Sci. 7:585787. doi: 10.3389/fvets.2020.585787

In the original article, there was an error. An incomplete disclaimer was used.

A correction has been made to Disclaimer:

Disclaimer: The findings and conclusions in this publication are those of the author(s) and should not be construed to represent any official USDA or U.S. Government determination or policy. Mention of any trade name, proprietary product or specific equipment does not constitute a guarantee or warranty by USDA-ARS and does not imply its approval to the exclusion of other products that may also be suitable. The USDA-ARS is an equal opportunity and affirmative action employer and all agency services are available without discrimination.

The authors apologize for this error and state that this does not change the scientific conclusions of the article in any way. The original article has been updated.

Copyright $\odot 2020$ Marchant-Forde and Boyle. This is an open-access article distributed under the terms of the Creative Commons Attribution License (CC BY). The use, distribution or reproduction in other forums is permitted, provided the original author(s) and the copyright owner(s) are credited and that the original publication in this journal is cited, in accordance with accepted academic practice. No use, distribution or reproduction is permitted which does not comply with these terms. 